\title{
إعادة تهيئة الأسطح القائمة كقيمة بيئية و اقتصادية مضافة دراسة حالة: عمارات العبور - مدينة القاهرة \\ Retrofitting existing conventional roofs as an environmental and economic added value Case study: El Obour Buildings - Cairo City
}

\author{
أ. أ.م.دياسر محمد السيد \\ أستاذ مساعد العمارة بكلية الفنون الجميلة ، جامعة حلوان.

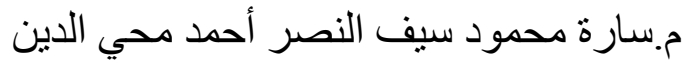

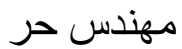

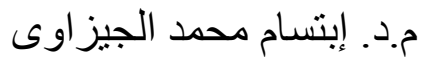 \\ مدرس بقسم العمارة بكلية الفنون الجميلة ، جامعة حلوان .
}

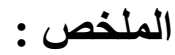

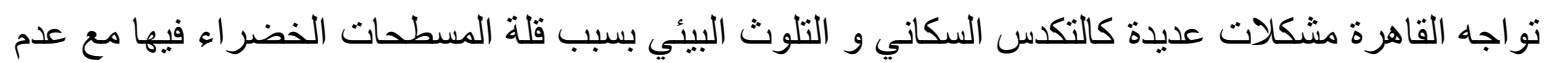

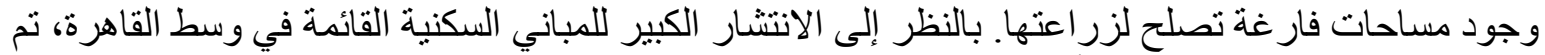

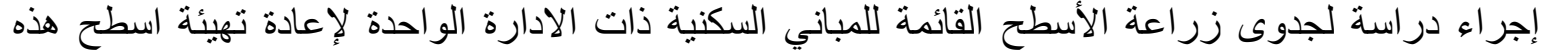

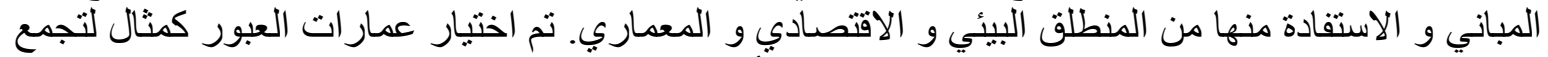

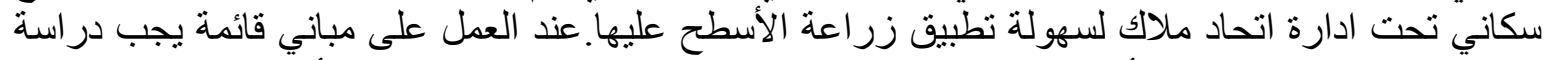
النوع المستخدم في زر اعة الأسطح من حيث الاحمال و طريقة التركيب المناسبة لهذه الأسطح.

\begin{abstract}
:
Cairo faces many problems such as overpopulation and environmental pollution due to the lack of green spaces in it, with the lack of empty spaces suitable for cultivation. In view of the large spread of the existing residential buildings in central Cairo, a study was conducted on the feasibility of greening the existing roofs of residential buildings with one unity to retrofit the roofs of these buildings and make use of them from an environmental, economic and architectural point of view. El Obour residential buildings were chosen as an example of a populated group of buildings under the one association of the Union of Owners in order to ease the application of roof greening to them. In case of working on existing buildings, the type used in roof greening must be studied in terms of loads and the appropriate installation method for these roofs.
\end{abstract}

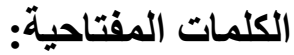

الأسطح الخضراء، إعادة التهيئة للمباني السكنية، الاحمال الانشائية، الدحاصيل الزراعية، عمار ات العبور. 


\section{Keywords:}

Green roofs, Retrofitting residential buildings, Structural loads, Vegetation, ElObour buildings.

\section{Introduction:}

Like many other cities, Cairo faces constant pressure from increasing rates of urbanization. There are almost no green spaces within Cairo in addition to the overcrowding of buildings next to each other's as well as the narrow width of streets. All these issues have prompted to many environmental problems, such as air contamination problems and the heat island phenomenon, the residential sector consumes $40 \%$ of the total energy consumption in Egypt. As a result, green roofs are becoming popular breathing roof alternative to traditional roof systems. Despite environmental concerns all over the world, the rapid increase the rate of energy consumption, and the rising importance of green roofs, till now there has been limited knowledge in Egypt about how to use, manage and apply green roofs.

The aim of this research is to establish a theoretical framework to implement green roofs in Cairo, as a holistic approach for healthy productive cities. Green roof farming increase the availability of fresh and high quality vegetables, encourage a more efficient use of water, provide profit income to the residents. Replace the conventional roof's buildings to buildings with living concept by applying the suitable green roof system to reach the environmental and economic benefits from this application.

The research methodology is a mixed strategy as it needs a literature review on green roofs, review on conventional flat roofs problems, data collection and data analysis. As well as studying of implementation of Green Roof and its applicability and analysing the results.

1. Theoretical Approach

2. Analytical Approach

3. Deductive Approach 


\section{Cairo problems:}

\subsection{Population \& Pollution:}

Cairo has the largest metropolitan area in Egypt, 10.6\% of Egypt's total population; and the amount of green space per inhabitant is $0.33 \mathrm{~m}^{2}$ per person (one of the lowest proportions in the world); this is due to the high population per land especially at the downtown area where there is no free land spaces to green or plant. This leads to a huge problem such as low air quality which may cause climate change to the whole region in the long run.
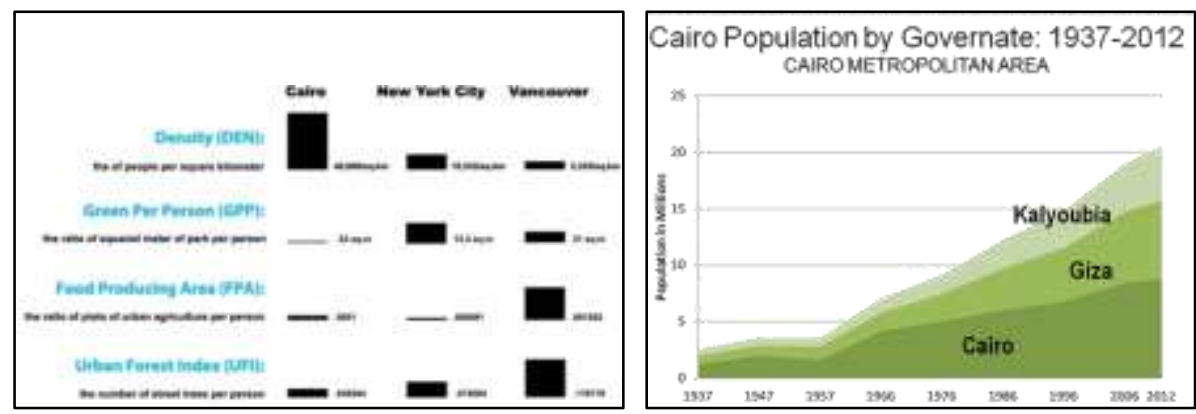

Figure 1.1 Cairo metropolitan area in Egypt and in around the World.

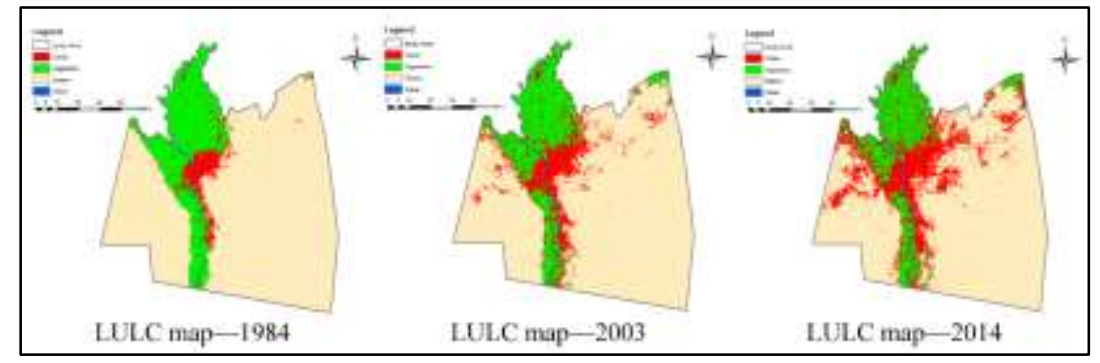

Figure 1.2 Greater Cairo population in during the past decades

The residential buildings in Cairo have the largest proportion of land use compared to the amount area of agricultural and green spaces, which produce large amount of pollution. Food and the life essentials are transported from the agricultural areas to Cairo and surrounding cities that consume large amount of energy and produce a large amount of $\mathrm{NO} 2$; thus, cause air pollution (low air quality). In fact, the dense concentration of automobiles and polluting buildings created a negative impact on the environment. In fact, the rapid urbanization not only created environmental problems but also economic problems. For example, air conditioners are running, over the whole summer period, from May to September, trying to deliver an endless demand for cooling. This is due to the lack of energy codes, which means that roofs are without or with very poor insulation. 


\begin{tabular}{|c|c|c|c|c|}
\hline \multirow{2}{*}{ LAND USE 2009} & Zone $1-23$ & \multirow{2}{*}{$\%$} & Zone $A, B$ and $C$ & \multirow{2}{*}{$\%$} \\
\hline & Fadden & & Fadden & \\
\hline Residential & 41385 & 30 & 64658 & 33 \\
\hline Industrial & $18170^{-}$ & 13 & 16879 & $\overline{9}$ \\
\hline Commercial & 2320 & 2 & 7124 & 4 \\
\hline Institutional & 11644 & 8 & 10189 & 5 \\
\hline Security, Army & 13560 & 10 & 3294 & 2 \\
\hline Cemetery & 1969 & 1 & 2231 & 1 \\
\hline Green areas & 5315 & 4 & 38143 & 20 \\
\hline Agricultural & 11939 & 9 & 128 & 0 \\
\hline Vacant, Desert & $11049^{-+-+}$ & 8 & 14772 & 8 \\
\hline Others & 20134 & 15 & 38072 & 19 \\
\hline TOTAL & 137485 & 100 & 195490 & 100 \\
\hline \multirow{2}{*}{ Non Built up } & Zones $1-23$ & \multirow{2}{*}{$\%$} & Zones $A, B$ and $C$ & \multirow{2}{*}{$\%$} \\
\hline & Fadden & & Fadden & \\
\hline Agricultural & 11939 & 38 & 128 & 1 \\
\hline Vacant & 3667 & 12 & 2496 & 17 \\
\hline Green & 76 & 0 & 0 & 0 \\
\hline Desert & 7382 & 24 & 12276 & 82 \\
\hline Army & 7903 & 26 & 0 & 0 \\
\hline TOTAL & 30967 & 100 & 14900 & 100 \\
\hline
\end{tabular}

Table 1.1 Land use and Non-Built up of Greater Cairo Region. Source: GOPP 2009

El Obour Buildings is an example of a group of residential buildings that suffers economic, environmental, visual and structural roof problems. And its location, area and unity give it preference to be chosen to improve the surrounding areas. Such example can be applied on similar buildings with one unity to assure applying the benefit experience.

Green roofs can work as a sustainable solution and are presented as an urban landscape for healthy and productive cities.

\begin{tabular}{|l|l|l|}
\hline $\begin{array}{l}\text { Environmental } \\
\text { Sustainability }\end{array}$ & Economic Sustainability & Social Sustainability \\
\hline Improve air quality & $\begin{array}{l}\text { Increase local food } \\
\text { production, sale and security }\end{array}$ & Local employment \\
\hline Mitigate urban heat island & $\begin{array}{l}\text { Reduce building cooling } \\
\text { load and energy costs }\end{array}$ & $\begin{array}{l}\text { Active community } \\
\text { participation in green spaces }\end{array}$ \\
\hline $\begin{array}{l}\text { Sound insulation and noise } \\
\text { absorption }\end{array}$ & $\begin{array}{l}\text { Access to open views } \\
\text { increase the property value }\end{array}$ & Increase level of awareness \\
\hline Reduce food transportation & $\begin{array}{l}\text { Offers employment and } \\
\text { Source of income for } \\
\text { housewives }\end{array}$ & \\
\hline
\end{tabular}

Table 1.2: Prospects of applying Green roofs on Residential Buildings

\section{Green Roofs}

Green roofs are providing natural or adaptive vegetation to a building's roofing structure. In large urban areas, where vegetation is scarce, green roofs provide the essential elements for buildings to qualify some of the environmental impacts of urbanization. Green roofs also create habitats for animals and plants and in this way support biodiversity. For these reasons, they have become integrated in City's Urban Strategy for changing the urban image. 
Green roofs properly designed, constructed and maintained, are beneficial socially, environmentally and fiscally. They are an important tool to increase sustainability and biodiversity and decrease energy consumption, urban heat island impacts and greenhouse gas generation.

"It is not against all logic when the upper surface of a whole town remains unused and reserved exclusively for a dialogue between the tiles and the stars?"

(Le Corbusier)

Green roofs protect the building and its surrounding environment by two ways, shading and evapotranspiration:

Shading: The growing medium and specially engineered soil, blocks the sunlight reaching the under layer roof membrane, while the vegetation (plants and trees) emits some amount of sunlight and shade the surface below them.

Evapotranspiration: Plants absorb water through their roots and emit it through their leaves - this movement of water is called transpiration. Evaporation, the conversion of water from a liquid to a gas, also occurs from the surfaces of vegetation and the surrounding growing medium. Together, the processes of evaporation and transpiration are referred to as evapotranspiration. Evapotranspiration cools air by using heat from the air to evaporate water.

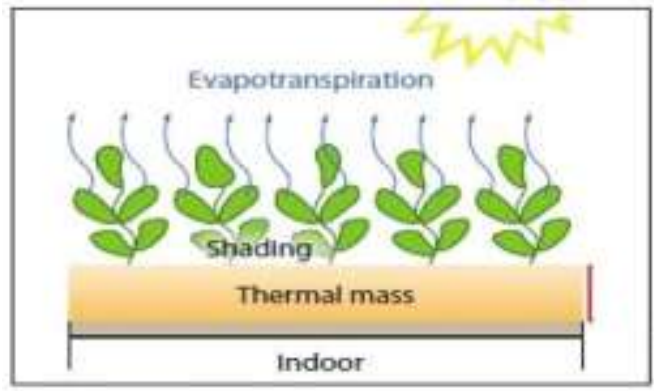

Figure 2.1 Evapotranspiration and Shading on a Green Roof.

\subsection{Conventional Flat Roofs.}

All roofs have a waterproof membrane to keep precipitation out of the building conventional roof puts the waterproof membrane at the top of the roof where it is subject to environmental forces such as wind, temperature and ultra-violet radiation. When a green roof is installed, it acts as a protective barrier for the waterproof membrane, extending its life. A regular flat roof usually needs to be replaced every 10-15 years. Green roofs can at least double life of a roof. One of the factors affecting the life of a roof is the temperature. A conventional roof often has pavers or gravel on top of the membrane to provide some protection. Daytime temperatures on a conventional rooftop can range between $-2^{\circ} \mathrm{C}$ in winter and $50^{\circ} \mathrm{C}$ in summer. A green roof layer $10 \mathrm{~cm}$ thick can reduce this range to between $10^{\circ} \mathrm{C}$ and $30^{\circ} \mathrm{C}$, resulting in less expansion and contraction stress on the membrane, reducing cracking and aging.

\subsection{Green Roofs Systems.}


Installation of Green Roofs occurs in more than one way. First, plants and soil are hauled onto a roof where planting occurs directly on top of the waterproof membrane. The second option involves prefabricated squares with growing medium and plants already sprouted. Other systems are soilless such as Hydroponics system and Aeroponics system.

The layers of a typical green roof include:

\subsubsection{Root Barrier Layer:}

The root barrier is the first layer above the building's roofing assembly that generally is built out of traditional materials like concrete. The main purpose of this layer is to provide a waterproof membrane to the roofing assembly. Another purpose of this layer, as the name suggests, is to protect the building's roofing assembly from plant's roots that could penetrate from green roof's upper layers resulting in cracks and holes where water infiltrates.

\subsubsection{Drainage Layer:}

It is important to provide an empty space between the layers to allow the excess water to freely move out of the roof. It decreases the risk of water leaks to the roofing assembly. In addition, water adds an extra weight to the roof assembly; therefore it is essential to ensure a good drainage to maintain structural capacity of the roof assembly. Effective drainage protects the root barrier from the excess water that can be accumulated in the membrane.

\subsubsection{Filter Layer:}

The purpose of the filter layer is to prevent the fine particles of the upper layers from draining with water runoff to lower layers and block the drainage layer during the draining process. In addition, the filter layer maintains the integrity of the growing medium and vegetation.

\subsubsection{Water Retention Layer:}

Water retention layer is a mat made out of mineral wool or polymeric fibres and is installed just above the filter layer to retain water for runoff control and keep the growing medium layer moist. Water is a natural source of nutrients for plants and help vegetation to be healthy to survive on roof tops.

\subsubsection{Growing medium Layer:}

This layer contributes to thermal performance and water retention, besides it supplies nutrients and water that plants need to their biological functions. Additionally, it provides space to plant roots to settle and strengthen, to withstand wind force and other rough weather conditions, on the roof tops.

\subsubsection{Vegetation Layer:}

Vegetation layer is the esthetical layer (symbol) of green roofs. However the purpose of growing plants on roof tops, besides esthetical, are to mitigate urban heat effect, improve air quality, replace displaced landscape, and enhance biodiversity. 
Moreover plants play an important role in regulating storm water runoff by retention and evapotranspiration processes.

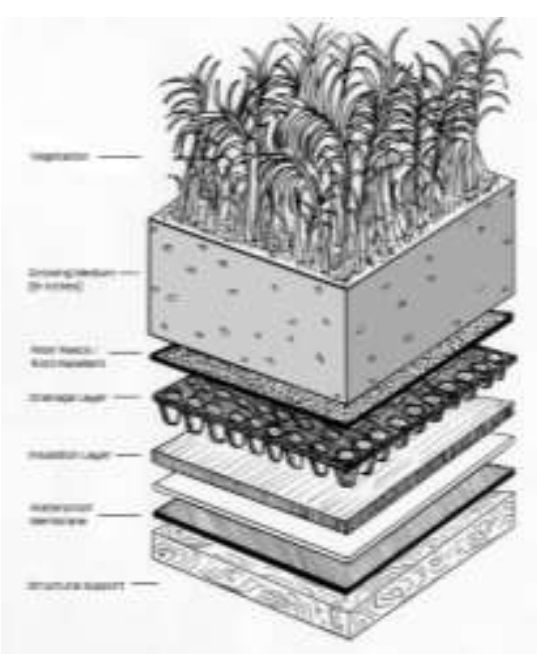

Figure 2.2 Typical green roof layers.

The growing medium thickness differs by the type of plants planted on.

The Other systems of greening roofs with a growing medium are Wooden Hotbeds or Plastic Hotbeds, PVC pipes, Plastic barrels and Plastic bags. These systems have more economic benefits than the typical green roof system as they are lower in cost of installation, has easy installation, easy maintenance, low risk on existing and old roof slabs.

The other soilless systems of green roof, by planting in nutrient solutions such as planting in pipes fixed on wall, planting in water sinks, or planting in plastic trays.

\subsection{Typical Green Roof Types.}

Green roofs can be classified by their purpose and characteristics in to two major types: intensive roofs and extensive roofs, and there is a third type of green roof is called semi intensive, which is a combination of extensive and intensive green roofs.

\subsubsection{Intensive Roof Greening.}

Intensive green roofs generally have from 150 to $1200 \mathrm{~mm}$ of growing medium, which will support larger plant life. Larger bushes and even trees can be planted on intensive green roofs. However, this imposes a large dead and live weight load on the roof of the building that requires additional structural support.

\subsubsection{Extensive Roof Greening.}

An extensive green roof has between 50 and $150 \mathrm{~mm}$ of growing medium to support plans life. This limits the size of plants that can be used on the roof, thus limiting the weight of the green roof on the building structure. Often this type of green roof is retro-fitted to existing buildings, so that the existing roofs structural support will not have to be augmented or replaced. 


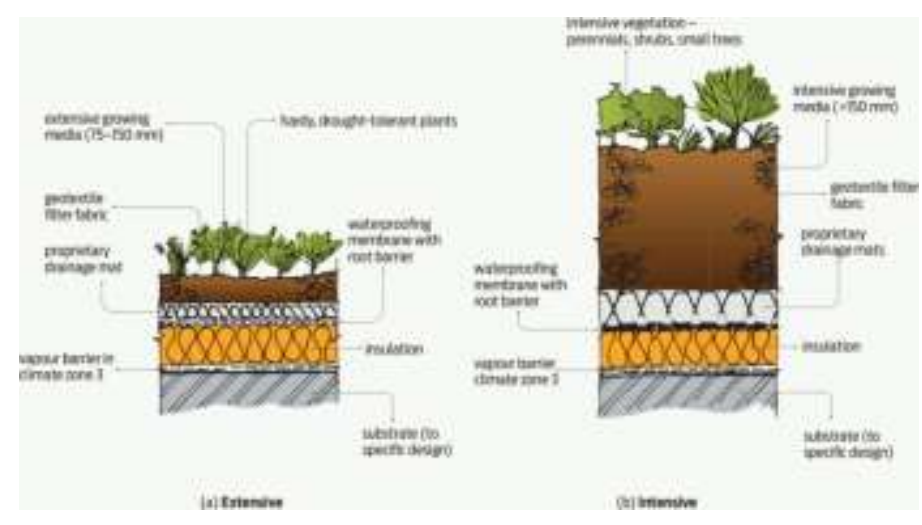

Figure 2.3 Typical Installation Components of Intensive and Extensive Green Roofs.

2.3.3. Semi-Intensive Roof Greening and hybrid types.

The future of green roofs is going to be a hybrid future, where the best elements of all traditions are combined to create sustainable rooftop environments in all contexts. Therefore the semi-intensive green roof has a deal of potential for the creative extension of roof planting where the roof area is visible and intended for human use. Semi extensive roofs have the same low or no-input philosophy as the extensive roof and use similarly light weight substrates and modern green-roof construction technologies, but they have slightly deeper layers of growing medium $(10-20 \mathrm{~cm})$ and therefore enable a wider and more diverse of plants to be grown.

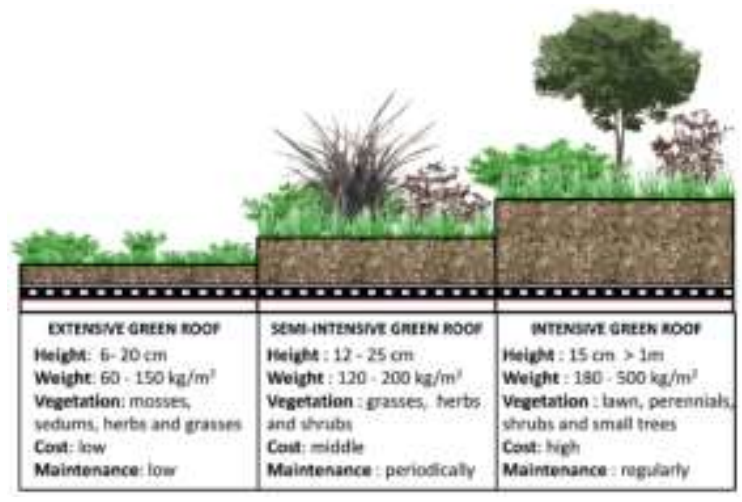

Figure 2.4 Comparison between Intensive, Semi-Intensive and Extensive Green Roofs.

\subsection{Soilless Green Roof Types:}

Soilless Green roofs types can be classified by the type of their growing medium and the system of irrigation. The growing medium in these types are soilless, but can be other media materials, hydroponics or aeroponics. The soilless media culture is an organic media or an inorganic media.

\subsubsection{Media Culture Green Roofs.}

This type means using solid media materials for the plant's roots, which can be organic materials such as Peat Moss, Sawdust or Bark combined with sand or perlite or vermiculite or other fertilizers in different ratios. While the inorganic 
materials contains particles such as (expanded clay, gravels, or sand), combined with foam or fibers such as rock wool and other substance such as perlite and vermiculite. The planting can be on trays or pots standing on wooden tables or barrels for trees that need to extend their roots. While the irrigation can be manual or by using an automatic irrigation system.
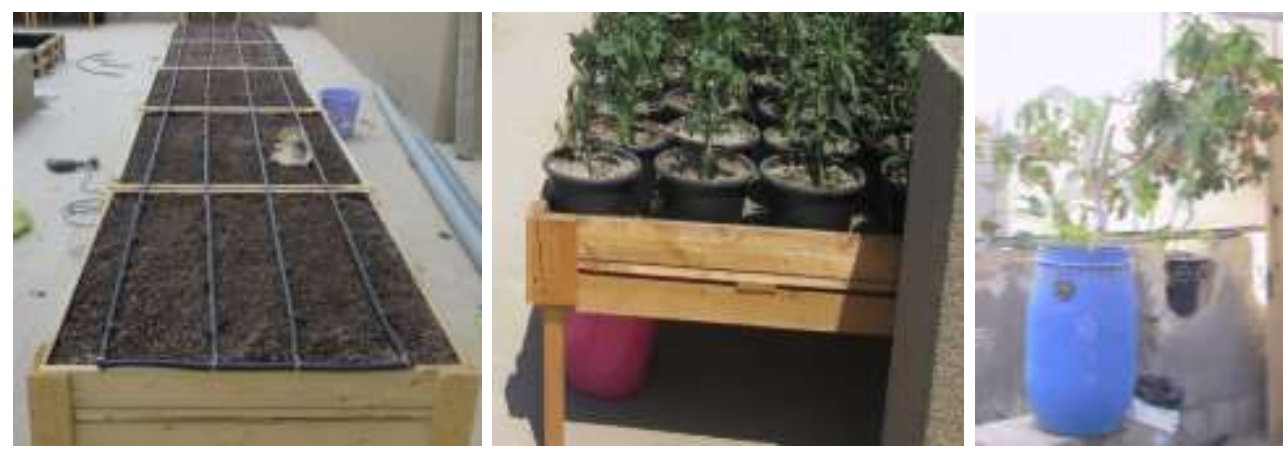

Figure 2.5 Different systems for media culture green roof

\subsubsection{Hydroponics Green Roofs.}

This type's media is liquid; the roots grow in liquid which is a combination between irrigation water mixed with nutritious solution that gives the vegetation the minerals needed. The vegetation can be in a deep hydro system or in pipes system that can be hanged on the wall or in a pyramid system.
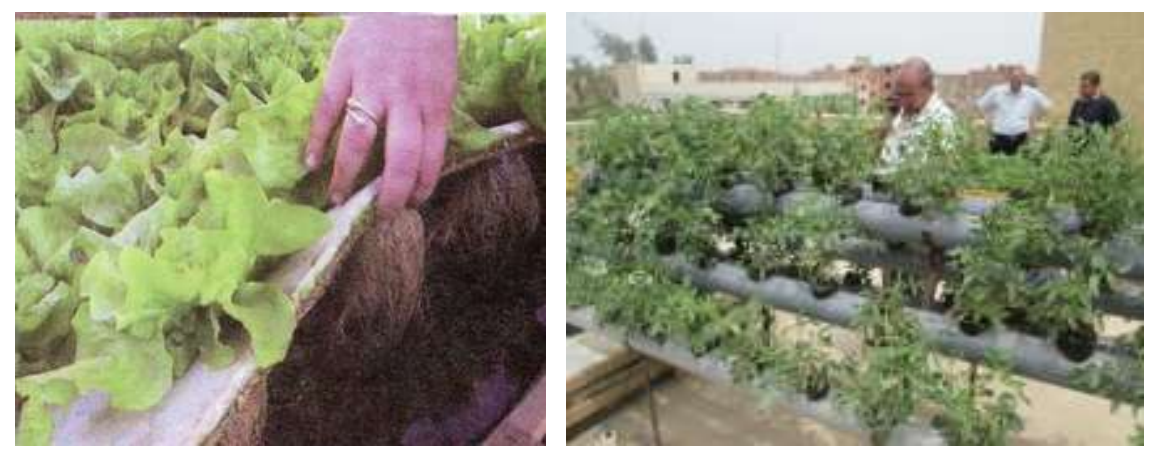

Figure 2.6 Different systems for hydroponic green roof

\subsubsection{Aeroponics Green Roofs.}

In this type the roots grow in the air and the vegetation gets its nutritious growth needs by spraying the water mixed with nutritious solution that form the mist/fog around it. 

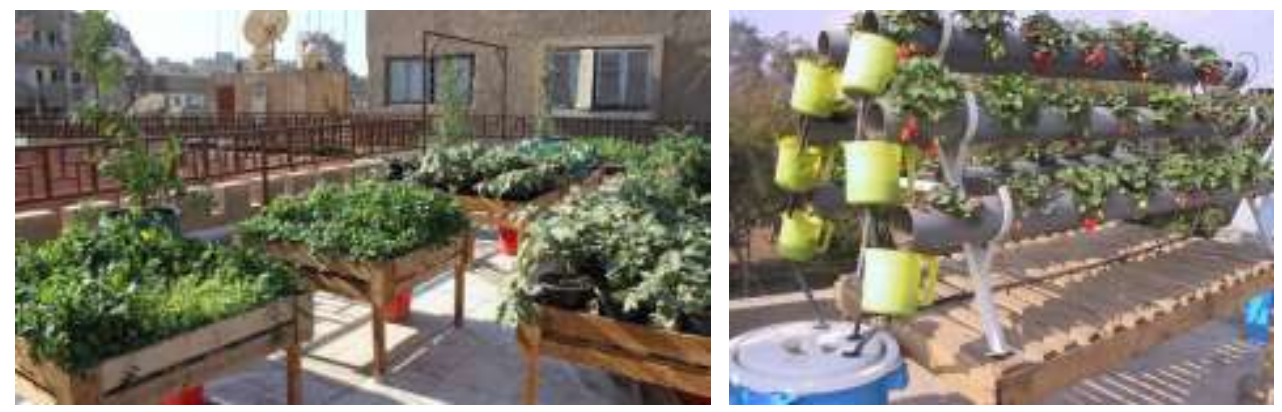

Figure 2.7 Different systems of soilless greening roofs.

\section{Quality of life.}

"Urban Design creates spaces for people, but not just a physical space rather an all-encompassing approach inclusive of the social processes which will occur there. The goal of Urban Design is to produce places where quality matters."

(Peck, 2005)

If we turn our eyes towards the sky, we will see several thousands of square meters of unexploited potential on the cities' roofs - in other words, a vast potential for transforming our traditional cities to green life-giving oases. Here lie the seeds of future urban design.

Thus, Good Urban Image is a good Quality of Life in which includes: urban heat islands, visually city image, improved air quality, reduce storm water runoff.

In the following years, researchers, landscape architects and contractors tested different techniques to build green roofs and studied their benefits. They found a multitude of advantages for the individual building, as for the whole city. Storm water retention, climate moderation (inside and outside), noise reduction, increased roof life, dust filtration and wildlife value, and, visual improvement were the main attributes accredited to green roofs.

\section{Benefits of green roofs}

\subsection{Environmental benefits of installing green roofs on rooftop buildings.}

\subsubsection{Reduce Urban Heat Island Effect}

Heat island effect can be mitigated by installing green roofs in urban areas. Trees and plants help to control the ambient temperature by evapotranspiration. In open areas plants use solar energy to control temperature by releasing vapor and contributing to the water cycle, while in urban areas there is not enough to cool down the environment. 


\subsubsection{Increase Cooling Loads}

Green roofs can reduce the amount of sunlight that is absorbed by the roofing material. Instead, the vegetation acts as a natural cooling mechanism for the building, lower temperatures for building roofs and the air above them in most climates

\subsubsection{Improves Environmental Air Quality}

Green roofs contribute to reduce air pollution and reducing $\mathrm{CO} 2$ in the atmosphere in two ways:

- First, carbon is a major component of plant structures and is naturally sequestered in plant tissues through photosynthesis and into the soil substrate via plant litter and root exudates and stores it as biomass.

- Second, they reduce energy needs by insulating individual buildings and by mitigating the urban heat island.

Green roofs also provide extensive environmental air quality benefits through the ability to absorb not only greenhouse gases such as carbon dioxide, but also pollutants and dust.

\subsubsection{Decreased Storm water Runoff}

The plants and growing medium of a green roof, in the same manner as other natural surfaces and vegetation, absorb water that would otherwise become runoff. Green roofs also improves water quality due to reduced storm water runoff and fewer overflows of combined sanitary and storm water sewage systems. Adaptive vegetation on a building's roof can significantly improve rainwater quantity and quality.

\subsubsection{Biodiversity}

Increased habitats, and promoting biodiversity. Native and adaptive vegetation on building rooftops can provide habitat for otherwise displaced plants and can provide habitat for animals and insects that can maintain the life of green roofs.

\subsubsection{Noise Reduction}

Controlling noise is another reason to choose green roofs. Soil, plants, and the air layer trapped between the green roof assembly and the building surface provide sound insulation. The substrate blocks lower frequencies, while the plants block higher frequencies.

\subsection{Economic benefits}

\subsubsection{Improving Building Insulation}

Green roofs work as an insulation layer for buildings. Thickness of the growing medium and plants protects rooftops from fluctuations in weather conditions. A green roof reduces heating costs in the winter and cooling costs in the summer by reducing the amount of heat transfer between the roof surface and the atmosphere. 
Scientists estimate that strategically planting trees and vegetation reduces cooling energy consumption by up to $25 \%$.

\subsubsection{Extended Roof Lifespan}

Green roof can provide extra protection for the building's roofing structure, from mechanical damage to ultraviolet radiation. Green roofs typically last twice as long as conventional roofs. The expected life span of green roofs varies from 40 to 55 years, while the life of conventional roofs is about 20 years.

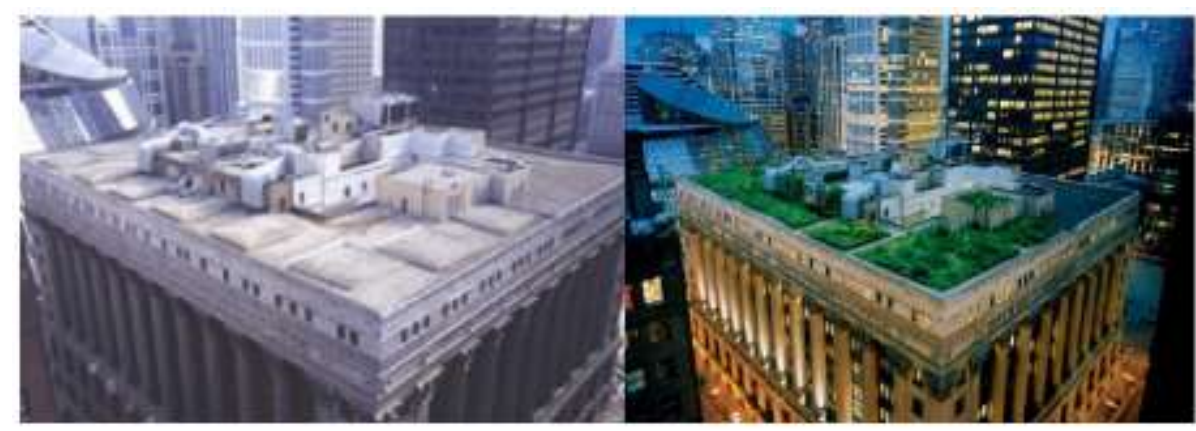

Figure 4.1 Green roof increases Chicago Hall lifespan

\subsubsection{Reduced energy consumption in some climates}

The thermal effects of green roofs can be divided into two aspects:

- Direct effect to the building (internal) - the heat transfer through the roof to the building interior which is the concern on building energy use.

- Indirect effect to the surrounding environment (external) - the heat transfer from the roof to the surrounding environment which is the concern for urban heat islands.

When the urban temperature is reduced, it will benefit all the buildings in the area or city and enhance energy conservation.

\subsubsection{Green roofs increase the functionality of buildings and cities}

The work of the Urban Green Spaces Task Force demonstrated the various benefits that green space provide, such as ecological function, visually softening the built environment, supporting roofs biodiversity, aiding people's mental and physical health, and providing a communal focus and sense of place.

The scale of these benefits is truly impressive and justifies a much more aggressive set of policies and incentives to help advance the adoption of green roofs and cool roofs in our region. Municipalities and counties should provide guidance and incentives for residential and commercial private party installations of green roofs and cool roofs to increase their use in our communities.

\section{Structural evaluation of additional load on the roof surface.}

The first phase in retrofitting a building with a green roof is to determine the existing load-bearing capacity. Because a green roof adds to the load on the roof 
structure, it is necessary to determine over-loading in relation to diff erent green roof configurations and to compare it with the residual load bearing capacity of the building structures. The load that can be applied on the flat roofs of residential buildings is $200 \mathrm{~kg} / \mathrm{m}^{2}$ (about $1.96 \mathrm{kN} / \mathrm{m}^{2}$ ), according to the European standard. This $200 \mathrm{~kg} / \mathrm{m}^{2}$ is considered usable during the design phase, but $50.98 \mathrm{~kg} / \mathrm{m}^{2}$ is considered necessary for maintenance. Therefore, the maximum additional load allowed for installation of a green roof on an existing building is $148.9 \mathrm{~kg} / \mathrm{m}^{2}$.

The substrate materials load is calculated in dry density, while the irrigation water, precipitation and evapotranspiration has a role during the application and add more load. To calculate the added load a previous experimental study was made on substrates and drainage materials; using the following equation to correlate the dry density $\gamma_{\mathrm{d}}$ with the saturated density $\gamma_{\mathrm{s}}$ of the substrate:

$\underline{\gamma}_{\underline{s}}=\gamma_{\underline{d}}+\mathbf{n} \gamma_{\underline{w}}$

where $\gamma_{\mathrm{w}}$ is the density of water $\left(1000 \mathrm{~kg} / \mathrm{m}^{3}\right)$ and $\mathrm{n}$ is the porosity of the substrate expressed as a pore volume percentage.

The substrates and drainages were combined to compare the additional loads determined for the diff erent green roof solutions. It was thus possible to identify the combinations most suitable for the retrofitting of existing buildings.

\subsection{Load analysis results}

The dry and saturated density of the diff erent substrates was analysed. Significant diff erences emerged between the dry density and the density calculated under saturated conditions. This diff erence is due to the substrate composition. In fact, lighter substrates, that consist mainly of coco peat and compost, which are materials with lower dry density values $\left(0.07\right.$ and $0.24 \mathrm{~g} / \mathrm{cm}^{3}$, respectively), while heavier substrates, that had a large percentage of crushed building wastes (dry density of $0.494 \mathrm{~g} / \mathrm{cm}^{3}$ ), sand (dry density of $0.457 \mathrm{~g} / \mathrm{cm}^{3}$ ), and Pozzolana. Furthermore, light substrates exhibited high percentages of porous silica.

On the basis of the mentioned thicknesses for both drainage and substrate, the additional load of the diff erent green roof configurations was calculated. The results reveal that, considering the load limit on the roof of existing buildings (148.9 $\mathrm{kg} / \mathrm{m}^{2}$ ) only a few green roof solutions are suitable for the retrofitting of existing buildings.

\section{Retrofitting Conventional Roof (Case Study: El Obour Buildings)}

\subsection{Intro \& Problems}

El Obour buildings is located in Heliopolis; which is considered as one of a new settlements in the last century, but nowadays it is one of an over populated areas in Cairo that have lack in green spaces and free spaces. El Obour buildings were considered as residential buildings but nowadays it has residential, commercial and admin. 

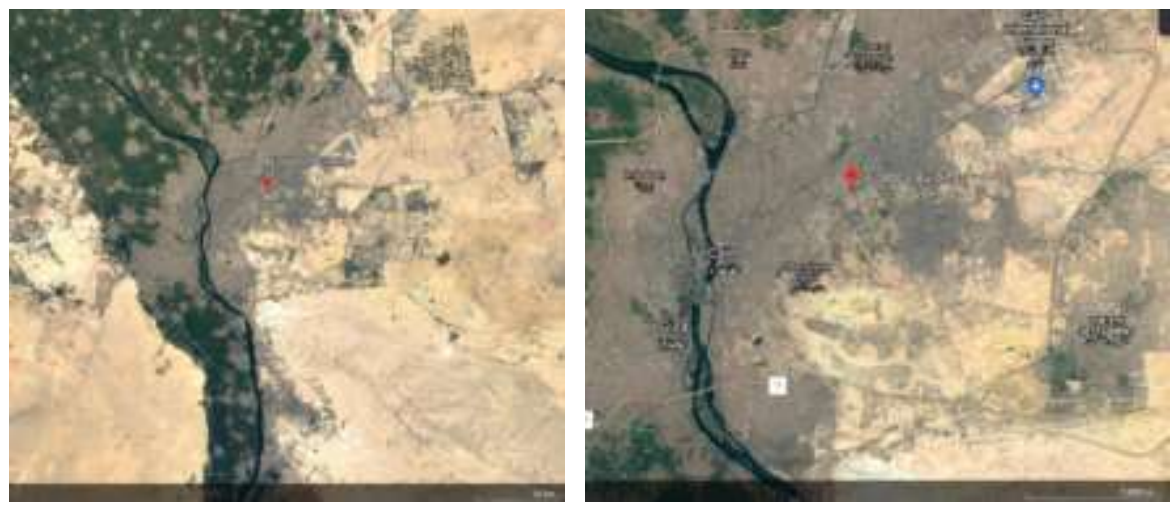

Figure 6.1 El Obour buildings in the center of area populated area
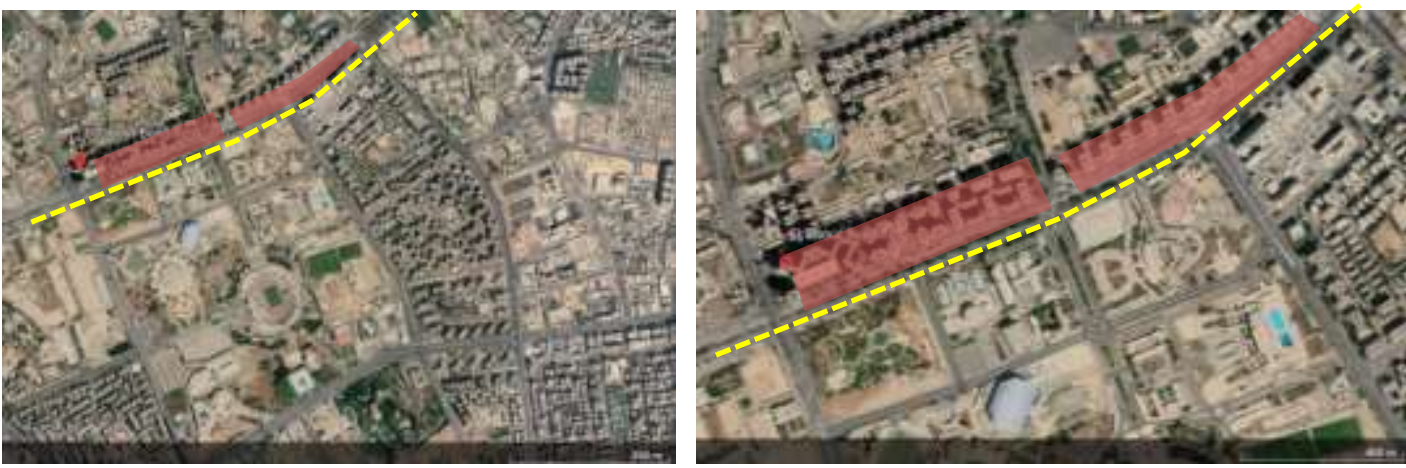

Figure 6.2 El Obour buildings \& Salah Salem Road

El Obour buildings are on Salah Salem road; one of the most high traffic and crowded roads in Cairo, and export a lot of $\mathrm{CO}_{2}$ from the cars engines. The buildings were build-up since a long period, which led to consuming the building infrastructure and needs a lot of maintenance cost. Each building has around 124 apartments, around 60 apartments are residential and the rest are admin and commercial. The buildings are under owners' unity association, and expense high maintenance cost, 200 L.E. per month for residential apartments while the commercial and admin apartments pay 400 L.E. per month, that counts more than 450,000 L.E. per year for each building.
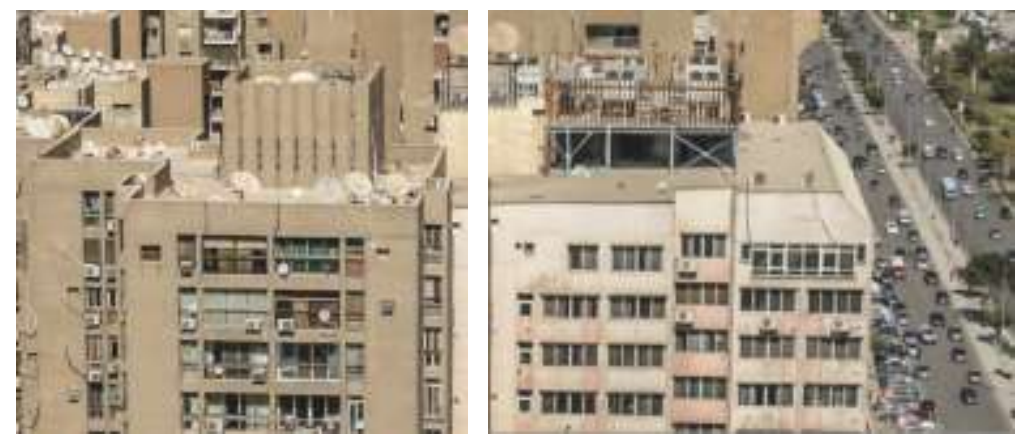

Figure 6.3 El Obour buildings existing roofs

The rooftops are now not used, but it's considered as storage for the non-used items, TV's satellites, and other items. These items have visual pollution and are not safety 
at all and can cause fire at any time. All the trash stored at the rooftops is a good living environment for insects such as mosquitos, flies, rats, reptiles like cockroach, etc. that can have a negative effect on the residents health in the long run.

Green roofs can be a local economic project for these buildings, by planting the daily essential food for the people in the buildings and save the transportation cost. Green roofs also offers employment and income for the housewives, or can provide income that can pay part of this maintenance costs. Green roofs also can perform as a lung for the surrounding area, absorb the $\mathrm{CO}_{2}$ emitted from the high traffic, air conditions at each apartment... etc. and provide $\mathrm{O}_{2}$ that is beneficial for the environment. Each $1 \mathrm{~m}^{2}$ of greening can remove $100 \mathrm{gm}$ of air pollutants per year, while by planting $1.5 \mathrm{~m}^{2}$ of green roof can provide the needed oxygen for an adult person for one while year.

\subsection{Case Study:}

El Obour buildings have total area around $38,750 \mathrm{~m}^{2}, 35$ buildings 15 at its $1^{\text {st }}$ phase and 20 for its $2^{\text {nd }}$ phase.

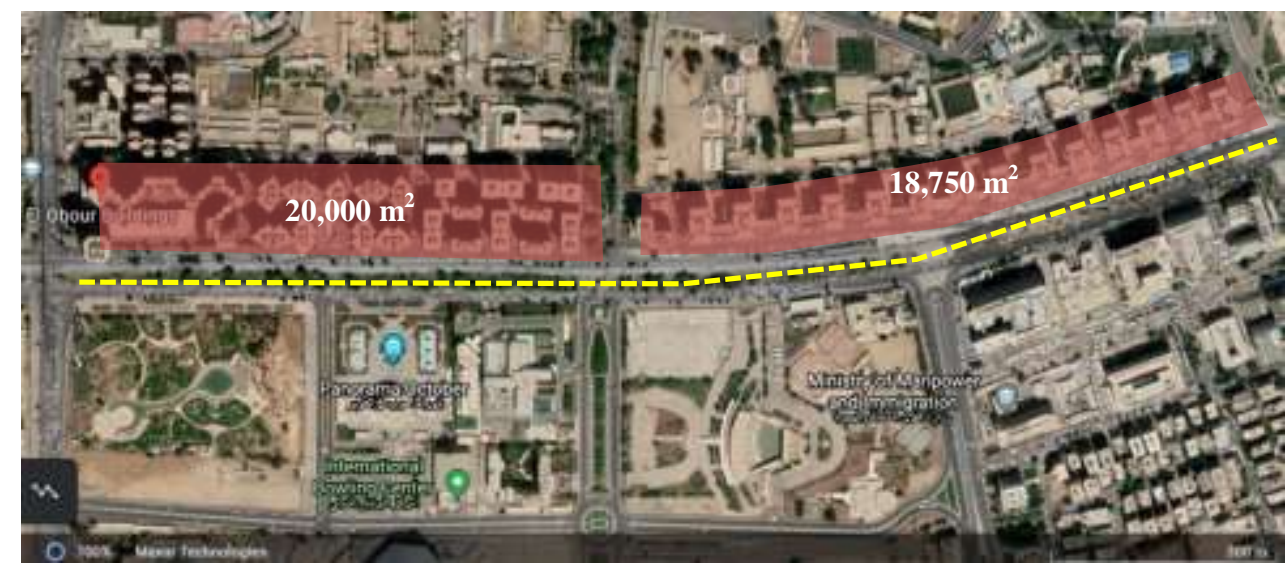

Figure 6.4 Total areas of El Obour buildings

Each building at its $1^{\text {st }}$ phase has 16 floors and 22 floors at its $2^{\text {nd }}$ phase with area around $1250 \mathrm{~m}^{2}$ in $1^{\text {st }}$ phase and $1000 \mathrm{~m}^{2}$ in $2^{\text {nd }}$ phase for each building and an empty space for vegetation about $995 \mathrm{~m}^{2}$ and $708 \mathrm{~m}^{2}$ respectively; around a good space that can fit a rooftop garden with different types of vegetation such as leaf crops, vegetables and fruits. 


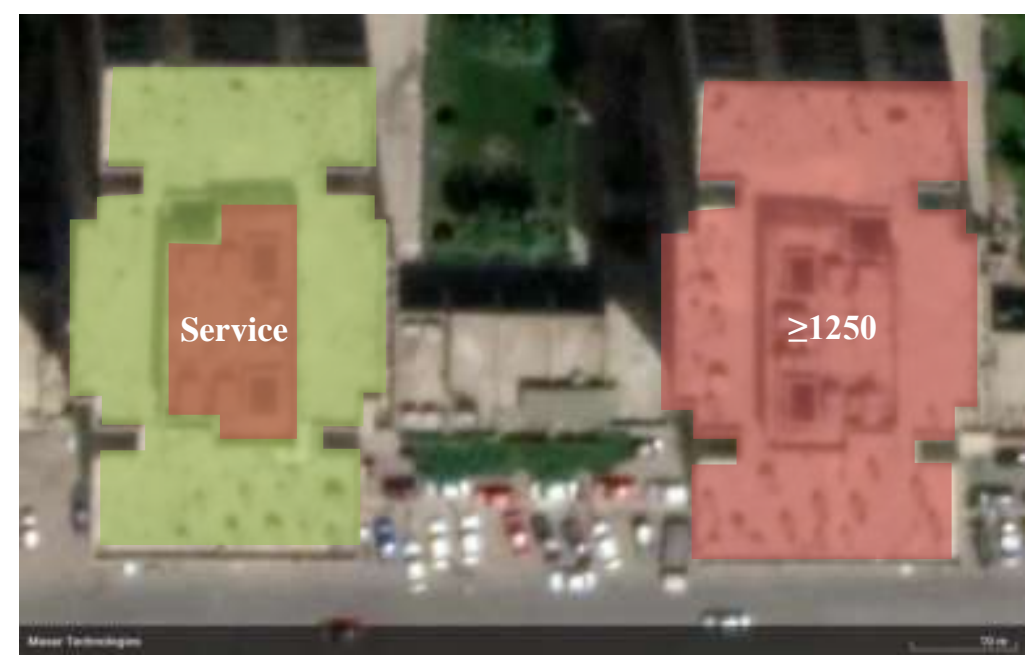

Figure 6.5 Total building $\&$ free rooftop areas that can be greened in $1^{\text {st }}$ phase.

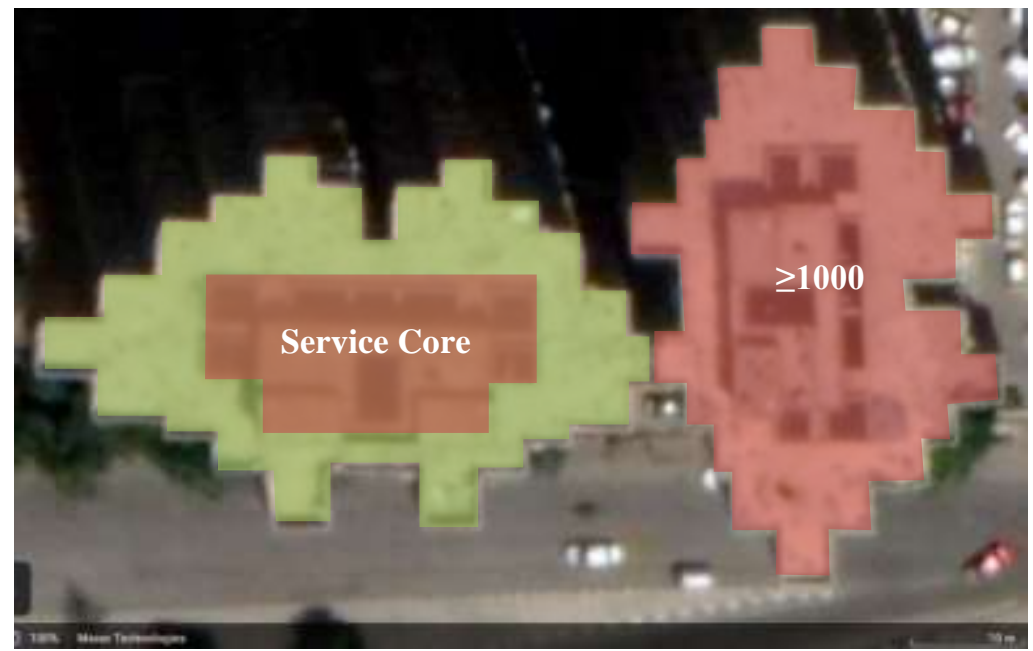

Figure 6.6 Total building \& free rooftop areas that can be greened in $2^{\text {nd }}$ phase.

Types of vegetation to be planted should be chosen before installing the system type of green roof applied. In our case we need vegetation with the highest income as there are economic problems need solutions. A research was done on 2013 by the Central Laboratory of Agricultural Climate - Agricultural Research Center around the economic benefits of planting each type of vegetation and type of greening roofs, the results where an average gain profit 0.10-0.80 L.E. per each 1.00 L.E. spent on greening $1 \mathrm{~m}^{2}$ of roof by using wooden tables/trays method. The most profit gain vegetation was the mulukhiyah, red and white radish, rocca leaves, celery, then lettuce, green beans, then eggplant, cabbage, then strawberries and tomatoes.

The planted area depends on the type of vegetation planted, for example the leaf crops like (rocca leaves, radish, coriander, parsley, dill, mint, basil, thyme ...etc. needs a wide horizontal space for its roots to expand so it can be planted directly on (extensive green roof or on wooden tables/trays), while vegetation like (tomatoes, cucumber, eggplant, broccoli, zucchini, pepper ..etc.) needs a moderate space for its 
roots to extend and expand so it can be planted on (extensive green roof or in wooden tables/pots). Vegetation such as (strawberries, green beans, lemons, grapes, peach, .. etc.) needs a big space for its roots to extend so it can be planted on (intensive green roof or hanged plastic bags or plastic barrels).

In our project there are a lot of apartments that need a high income to suffice the maintenance costs. Therefore, we need to increase the number of plants and vegetation on the surface to create a high plant density in order to intensify the production from the whole rooftop. A condenser green roof uses one or more green roof system, such as soilless media culture and hydroponic systems.

Each $100 \mathrm{~m}^{2}$ of a roof top can design $60 \mathrm{~m}^{2}$ green roofs after leaving space for pathways between the systems; as for the roof handrail if it is $1 \mathrm{~m}$ height for the same $100 \mathrm{~m}^{2}$ roof top it can plant $40 \mathrm{~m}^{2}$ of hydroponic system. Thus, a $100 \mathrm{~m}^{2}$ roof top can plant $60 \mathrm{~m}^{2}$ on floor and $40 \mathrm{~m}^{2}$ on wall.

In our case, the $1^{\text {st }}$ example of building with free roof top space $995 \mathrm{~m}^{2}$ can plant $597 \mathrm{~m}^{2}$ on floor and $398 \mathrm{~m}^{2}$ on walls, with total green roof $995 \mathrm{~m}^{2}$. The $2^{\text {nd }}$ example of buildings the free space rooftop is $708 \mathrm{~m}^{2}$ equal $708 \mathrm{~m}^{2}$ of green roof.

\section{Results \& Discussion:}

The results achieved from the research by the CLAC- ARC around the economic benefits of planting $1 \mathrm{~m}^{2}$ of each vegetation type in both winter and summer seasons on Soilless media culture and hydroponic systems with manual system for irrigation:

\begin{tabular}{|c|c|c|c|c|}
\hline Vegetation Type & $\begin{array}{c}\text { Media culture on } \\
\text { wooden trays }\end{array}$ & $\begin{array}{c}\text { Media culture } \\
\text { plastic pots }\end{array}$ & Hydroponics & $\begin{array}{c}\text { Profit per one } \\
\text { L.E. }\end{array}$ \\
\hline Zucchini \& lettuce & $\bullet$ & & $0.99 / 1$ L.E. \\
\hline $\begin{array}{c}\text { Red cabbage \& } \\
\text { tomatoes }\end{array}$ & $\bullet$ & & 0.28 / 1 L.E. \\
\hline $\begin{array}{c}\text { White cabbage \& } \\
\text { green peas }\end{array}$ & $\bullet$ & $\bullet$ & $-0.45 / 1$ L.E. \\
\hline $\begin{array}{c}\text { Chinese cabbage \& } \\
\text { green pepper }\end{array}$ & $\bullet \begin{array}{c}\text { Bussels sprouts \& } \\
\text { eggplant }\end{array}$ & $\bullet$ & $0.48 / 1$ L.E. \\
\hline $\begin{array}{c}\text { Lettuce \& green } \\
\text { beans }\end{array}$ & $\bullet$ & $\bullet$ & $0.59 / 1$ L.E. \\
\hline $\begin{array}{c}\text { Strawberries \& } \\
\text { tomatoes }\end{array}$ & $\bullet$ & & & $1.26 / 1$ L.E. \\
\hline $\begin{array}{c}\text { Mulukhiyah \& red } \\
\text { radish }\end{array}$ & $\bullet$ & & & $1.10 / 1$ L.E. \\
\hline Spanish \& parsley & $\bullet$ & & & $0.10 / 1$ L.E. \\
\hline Rocca \& celery & $\bullet$ & & & $0.70 / 1$ L.E. \\
\hline
\end{tabular}




\begin{tabular}{|c|c|c|c|c|}
\hline $\begin{array}{c}\text { Red radish \& } \\
\text { parsley }\end{array}$ & $\bullet$ & & $0.80 / 1$ L.E. \\
\hline $\begin{array}{c}\text { Brussels sprouts \& } \\
\text { eggplant }\end{array}$ & $\bullet$ & & & $0.20 / 1$ L.E. \\
\hline
\end{tabular}

Table 7.1: Vegetation types profit gain table

Direct extensive green roof can be installed too for the above vegetation types that are planted in the media culture wooden trays/ pots and hydroponic system and suitable for the residential roof greening use as its dead load $\left(60-150 \mathrm{~kg} / \mathrm{m}^{2}\right)$ is below the average residential dead load $\left(148.9 \mathrm{~kg} / \mathrm{m}^{2}\right)$, has low cost and maintenance. But portable systems such as wooden trays, plastic pots, and plastic barrels are much easier in installation, as you can get the complete system ready to be installed.

All the above green roof systems must have a well drainage system, that collect the excessive water of irrigation and can reuse this water after adding neutrinos to it but in lower ratios. The irrigation system can be manual and automatic for all the above systems, but in the automatic system you need to have a source of electricity to power the system, while the manual irrigation system must have a trained staff to obtain the highest advantage with highest income of the roof greening.

\subsection{Economic impact benefits:}

The $1^{\text {st }}$ example of buildings can offer a minimum profit 29.85 L.E. and maximum profit 1254 L.E., while the $2^{\text {nd }}$ example of buildings can offer a minimum profit 21.25 L.E. and maximum profit 892 L.E. for greening each building. By multiplying the average profit results of each phase:

$\underline{1^{\text {st }} \text { phase buildings: }}$

$(29.82+1254) / 2 \cong 642$ L. E. for each 1 L.E. spent, $(995 \mathrm{~m} 2 \times 15$ building $) \times 642=9,581,850$ L. E for each 1 L.E. spent.

$2^{\text {nd }}$ phase buildings:

$(21.25+892) / 2 \cong 456.625$ L.E. for each 1 L.E. spent, $(708 \mathrm{~m} 2 \times 20$ building $) \times 456.625=6,465,810$ L. E for each 1 L.E. spent.

\subsection{Environmental impact benefits:}

Each $1 \mathrm{~m}^{2}$ of green roofs reduce $100 \mathrm{gm}$, and each $1.5 \mathrm{~m}^{2}$ is enough for one person for one year.

$\underline{1^{\text {st }} \text { phase buildings: }}$

$(995 \mathrm{~m} 2 \times 15$ building $) \times 0.1 \mathrm{~kg}=1,492.5 \mathrm{~kg}$ of air pollutants per year, and $(995 \mathrm{~m} 2 \times 15$ building $) \div 1.5 \mathrm{~m} 2=9950$ person is provided by oxygen annually.

$\underline{2^{\text {nd }}}$ phase buildings: 
$(708 \mathrm{~m} 2 \times 20$ building $) \times 0.1 \mathrm{~kg}=1,492.5 \mathrm{~kg}$ of air pollutants per year, and (708 $\mathrm{m} 2 \times 20$ building) $\div 1.5 \mathrm{~m} 2=9950$ person is provided by oxygen annually.

\subsection{Discussion}

Over the last few years, rooftop gardens and farms have been recognized as a promising form of urban agriculture, and a way to take advantage of a significant amount of flat space that receives steady sunlight throughout the day. Using rooftop space for food production might help reduce the distance food travels to reach consumers, potentially reducing carbon emissions associated with food distribution. It could also provide fresh and local food options to building occupants and the local population. It could even provide an outlet to educate the local community about food production and seasonal variety. It could also boost property values through the addition of a new building service, and help create jobs.

By applying Green roofs at El Obour buildings as an example for similar buildings and studying the benefits resulted from such experience, it can be applying on buildings with similar situation, buildings under one unity, such as governmental buildings at Cairo downtown or at any informal district in Cairo and applied by its Sheriff.

\section{Conclusion}

This paper carried out a general overview on Cairo's environmental and economic problems, green roofs, its installation, systems, and some details on its types. The difference between each in the total thickness as it starts with $6-20 \mathrm{~cm}$ in the extensive green roof with weight $60-150 \mathrm{~kg} / \mathrm{m}^{2}$ while the semi intensive thickness is between $12-25 \mathrm{~cm}$ with weight $120-200 \mathrm{~kg} / \mathrm{m}^{2}$ and the intensive green roof total thickness $15 \mathrm{~cm}-1 \mathrm{~m}$ and weights $180-500 \mathrm{~kg} / \mathrm{m}^{2}$. While the soilless green roofs uses lighter substrates and substructures elements such as planting on wooden tables.

Furthermore, the research also highlighted on the environmental and economic benefits of applying green roofs on existing flat roofs. By studying the current structural limitations for adopting green roofs for retrofitting conventional/existing buildings roofs, thereby, the results of the study recommended allowing the appropriate choice of materials and thickness relative to the various layers constituting the green roof. This should be done in relation to the maximum applicable load on the flat roof of an existing building, and by providing useful information to the designers and constraints in all perspectives when adopting a green roof system for a building roof retrofit.

In Egypt, soilless agriculture is used to grow plants on the roofs of buildings. No direct planting process on the roof itself, instead, plants are grown on wooden tables, providing a fresh and healthy source of food that is pesticides free. 
No obvious reasons why green-roofs didn't spread in a country like Egypt, despite, responsive climate conditions and high rate of pollution. Vegetables and fruits can be produced as self-production for building users; moreover, many projects are running nowadays in schools as an introduction to this technology.

Furthermore, to increase the number of green roof solutions suitable for the redevelopment of existing buildings. Future research on new green roof materials should be carried out to develop solutions more suitable for application on existing buildings, considering their density under both dry and saturated conditions.

\section{References}

1. (Ayfer Baykal, Green Roofs Copenhagen)

2. GSA, a Report of the United States General Services Administration, The Benefits and Challenges of Green Roofs on Public and Commercial Building, May 2011.

3. Shady Attia and Alia Mahmoud, Green Roofs in Cairo: A Holistic Approach for Healthy Productive Cities

4. ianchini, Fbricio ; Hewage, Kasun ; "How "green" are the green roofs? Lifecycle analysis of green roof materials", Building and Environment, Volume 48, 2012.

5. Rowe, D. Bradley ; "Green roofs as a means of pollution abatement", Environmental Pollution, Volume 159, 2011.

6. MacDonagh, L. Petter ; RLA ; Martin, Roger B. ; FASLA ; "EPA"s Reducing Urban Heat Islands: Compendium of Strategies", Green Roofs Chapter (PDF), PP.29. http://www.epa.gov.

7. Fell, Stephen ; Lindum ; "A member of LEAF (Linking Environment and Farming)" http://www.lindumgreenroofs.co.uk

8. S.E. Ouldboukhitine, G. Spolek, R. Belarbi, Impact of plants transpiration, grey and clean water irrigation on the thermal resistance of green roofs, Ecol. Eng. 67 (2014).

9. H.F. Castleton, V. Stovin, S.B.M. Beck, J.B. Davison, Green roofs; Building energy savings and the potential for retrofit, Energy Build. 42 (2010).

10. J. Coma, A. de Gracia, M. Chàfer, G. Pérez, L.F. Cabeza, Thermal characterization of diff erent substrates under dried conditions for extensive green roofs, Energy Build.144 (2017).

11. D.J. Sailor, M. Hagos, An updated and expanded set of thermal property data for green roof growing media, Energy Build. 43 (2011).

12. C. Farrell, X.Q. Ang, J.P. Rayner, Water-retention additives increase plant available water in green roof substrates, Ecol. Eng. 52 (2013).

13. G. Pérez, A. Vila, L. Rincón, C. Solé, L.F. Cabeza, Use of rubber crumbs as drainage layer in green roofs as potential energy improvement material, Build. Environ. 97(2012).

14. Central Laboratory of Agricultural Climate - Agricultural Research Center, Directorate of Agriculture, Beni Suef 
Yasser Mohamed El Sayed / et al/ Engineering Research Journal 171(september 2021/ AA35- AA54 